\title{
Red Orphans' Fatherland: Children in the Civil War of 1918 and Its Aftermath
}

\author{
Mervi Kaarninen
}

\section{INTRODUCTION}

In the spring of 1918, the Civil War in Finland divided the nation into winners and losers-Whites and Reds. These divisions affected almost all citizens, including children. The war tore the society apart, and the consequences of the war were the most severe in families where one or both of the parents had lost their lives. There were families in which both parents were waiting to be sentenced to prison camps, that in the summer and fall of 1918 held about 70,000 people. ${ }^{1}$ After World War I in Europe, and in all the belligerent countries, the war orphans' generation was growing up. ${ }^{2}$

${ }^{1}$ Aapo Roselius \& Tuomas Tepora, eds, The Finnish Civil War 1918: History, Memory, Legacy (Leiden: Brill, 2014).

${ }^{2}$ Pignot, Manon, "Children," in The Cambridge history of the First World War Vol III: Civil Society, ed. by Jay Winter (Cambridge: Cambridge University Press, 2014), 29-45; Manon Pignot, Allons enfants de la patriae: Génération Grande Guerre (Paris: Èditions du Seuil, 2012); Andrew Donson, Youth in the Fatherless Land: War Pedagogy, Nationalism, and Authority In Germany, 1914-1918 (Cambridge: Harvard University Press, 2010); Bart

M. Kaarninen $(\bowtie)$

Tampere University, Tampere, Finland

e-mail: mervi.kaarninen@tuni.fi

(C) The Author(s) 2021

V. Kivimäki et al. (eds.), Lived Nation as the History of Experiences

and Emotions in Finland, 1800-2000, Palgrave Studies in the

History of Experience, https://doi.org/10.1007/978-3-030-69882-9_7 
In Finland, the situation had specific features. The Civil War left about 20,000-25,000 orphaned children, but the division into Reds and Whites also applied to the war orphans. The overwhelming majority of orphans were the children of the Red rebels, about 90 percent of 5000-5500 families. The families of the Reds were, as a rule, poor, and for a widowed mother, it was an impossible task to simultaneously try to survive with her children and earn a living without receiving any outside economic support. State officials knew to expect that children in the homes of the Reds would suffer from distress. ${ }^{3}$ If the husband and father had managed to survive the battles and the prison camp, his involvement in the war on the Red side would stigmatize him and his family for years to come.

The state authorities, charity workers and teachers understood that it was not possible to allow the children of the Reds to starve to death. These children needed food, constant care and careful upbringing in order to become good citizens in the new independent Finland. The organization of relief work had already begun at the end of April 1918 when the war had not yet ended. The National Board of Social Welfare, together with the National Board of Education and charitable and Christian associations, was responsible for the organization of the targeted relief work. In this salvation process, the aim was to build a thriving new Finland and a unified generation from the ruins of the Civil War. ${ }^{4}$ These actors understood that in the new independent state, the children and young people would form the future of the nation.

The children of the Reds had to be integrated into the shared fatherland, but how was this process to actually be made possible? Many of these children had lost everything: their father, their siblings and, in many cases, the security of their home. In this chapter, I examine how the children of the Reds understood and experienced the fatherland. They had witnessed

Ziino, "They seem to understand all about the war: Australian children and the First World War," Journal of History of Childhood and Youth, 11:2 (2018), 227-41; Aldis Purs, "Orphaned Testimonies: The Place of Displaced Children in Independent Latvia, 1918-26," in Placing the Child in Twentieth-Century History: Context and Framework, ed. by Nick Baron (Leiden: Brill, 2016), 40-69; Nazan Maksudyan, Ottoman Children \& Youth during World War I (Syracuse: Syracuse University Press, 1919), 11-15.

${ }^{3}$ Suomen sotaorvot, tilastollinen selonteko. (A statistical account of war orphans in Finland). Les enfants abandonnés par suite de la guerre. Statistique pour la Finlande. Résultats de l'énquete sur les habitations en 1919. Quelques données préliminaires. Revue sociale. L'administration générale des affaires sociale en Finlande 5 \& 6, 375-95.

${ }^{4}$ A. R. Rosenqvist, "Aikamme kulttuuri sekä individuaalinen ja sosiaalinen pedagogiikka," Kasvatus ja koulu 7:9 (1921), 253. 
the devastation of war and were growing up amidst contradictions in the new nation state on its way to peace and harmonization. I seek here to interpret children's emotions and experiences in White Finland. What kind of emotions were children taught and what kind of emotions did they have to eliminate ${ }^{5}$ How did pedagogues and teachers understand the children's emotions, such as grief, anger and bitterness? The children mourned their losses, while the winners' side organized victory celebrations and parades in honor of their war heroes. The children and orphans of the Reds found connections via the different emotional communities such as home, foster home, school and the children's own communities in the streets and on the playgrounds where they tried to respond to different expectations and demands. ${ }^{6}$ I use the concept of the emotional frontier, which historians of childhood Karen Vallgårda, Kristine Alexander and Stephanie Olsen define as a "boundary between different emotional formations." These emotional frontiers are difficult to traverse. For instance, in the case of the Red children, the state authorities and teachers, in their salvation process, had very different aims regarding emotional education and upbringing than did the parents; and the children, caught in the middle, needed to cross boundaries between different emotional communities. $^{7}$ At school, children were taught emotions, values and habits which were in contrast to the values according to which they were being raised at home, for example, in the case of education concerning love of the fatherland.

In this chapter, I focus on the city of Tampere where the Civil War and its consequences were felt deeply. Tampere was a key industrial center in Finland and the third largest town. The Battle of Tampere in early April 1918 was massive and particularly brutal. ${ }^{8}$ And the fall of "Red Tampere"

\footnotetext{
${ }^{5}$ About emotional education, see Karen Vallgårda, Kristine Alexander \& Stephanie Olsen, "Emotions in the Global Politics of Childhood," in Childhood, Youth and Emotions in Modern History: National, Colonial and Global Perspective, ed. by Stephanie Olsen (New York: Palgrave, 2015), 21.

${ }^{6}$ Barbara H. Rosenwein, "Worrying About Emotions in History," Journal of American Historical Review 107:3 (2002), 842-3.

${ }^{7}$ Vallgårda, Alexander \& Olsen (2015), 21-5; Josephine Hoegaerts, "Learning to Love: Embodied Practices of Patriotism in the Belgian Nineteenth Century Classroom (and Beyond)," in Emotions and Everyday Nationalism in Modern European History, ed. by Andreas Tynen, Maarten Van Ginderachter \& Xosé M Núňez Seixas (London: Routledge, 2020), 66-7.

${ }^{8}$ Risto Alapuro, State and Revolution in Finland (Berkeley: University of California Press, 1988); Tuomas Hoppu, "The Battle of Tampere," in Tampere 1918: A Town in the Civil
} 
marked the beginning of the end of Red rule in southern Finland. As research data, I use a large oral history collection entitled Tampere Political Heritage. The thematically structured interviews were conducted in 1972-76. ${ }^{9}$ They can be interpreted as life-story interviews including themes from early childhood until the 1970s. The Civil War and its aftermath were among the themes discussed and open a view on the war from a child's eyes. ${ }^{10}$ Each interview forms a life story where the narrator gives an account of his/her life via the reminiscence process and memory. The construction of the childhood experiences began in childhood. Life stories include people's own perceptions of their lives. They are influenced both by the time of the event, the Civil War, and the time of the narration, the 1970s. The life history includes the dimensions of the life story and the narrated life. It combines reconstruction of and reflection on one's past. Emotions like sorrow, bitterness and fear have been structured during the life span in different social and political contexts in light of the experiences undergone. ${ }^{11}$ And those experiences have had an impact on the narrator's world view. ${ }^{12}$ I have complemented the oral history material with documents from public authorities. The upbringing of the children of the Reds, how the fatherland was taught, and how the state understood its

War, ed. by Tuomas Hoppu \& Pertti Haapala (Tampere: Vapriikki, 2010), 44-139.

${ }^{9}$ In 1972, the History Committee of Tampere commissioned the Folklives Archive of the University of Tampere in the project "Tampere Political Heritage." The collection includes 222 interviews. Beginning in the early 1960s, archives and museums began to organize campaigns to collect written narratives from ordinary Finns about their personal experiences related to the Civil War and its aftermath. The narratives of the people who identified with the defeated side contained a lot of new information concerning the war. In Tampere, the Civil War had been "a lived experience," as people had commemorated the war in their various communities. Tiina Kinnunen, "The post-Cold War Memory Culture of the Civil War: Old-New Patterns and New Approaches," in Tepora \& Roselius (2014).

${ }^{10}$ For childrens' experience of war, see Ellen Schrumpf, "Childrens' Stories of WWII: A Study of Essays by Norwegian School Children from 1946," in Nordic Childhoods 1700-1960: from Folk Beliefs to Pippi Longstocking, ed. by Reidas Asgaard, Marcia J. \& Merethe Roos Bunge (New York: Routledge, 2018), 205-20.

${ }^{11}$ Valerie Raleigh Yow, Recording Oral History: A Guide for the Humanities and Social Sciences, 2nd ed. (Walnut Creek, CA: Altamira Press, 2005), 225-7; Lynn Abrams, Oral History Theory (Abingdon: Taylor \& Francis Group, 2010), 34-43; Alistair Thomson, "Life stories and Historical Analysis," in Research Methods for History, ed. by Simon Gunn \& Lucy Faire (Edinburgh: Edinburgh University Press, 2014), 101-17.

${ }^{12}$ Saara Tuomaala, "Sukupuolen kokemuksista muistitietohistoriaan," in Muistitietotutkimus: Metodologisia kysymyksiä, ed. by Outi Fingerroos et al. (Helsinki: SKS, 2006), 272-3. 
obligations to the orphans ${ }^{13}$ can be found in the documents of the poorrelief, child welfare and school administration authorities. Additionally, education ideology and pedagogy were discussed in the pedagogical journals of the time. ${ }^{14}$

\section{The Street and the Fear}

Locals lived in Tampere under Red Rule in the besieged town for two months. Children saw the Red Guards daily in marches, parades and funeral processions. They followed how the Reds practiced shooting and built barricades on the streets. During the Red Rule, unannounced and repeated house searches were conducted day and night in order to find hidden men, guns and foodstuffs. This continued after the Battle of Tampere when the Whites began to search for hidden Red Guards. ${ }^{15}$

The boys in Tampere could not stay away from the streets even when the battles were going on. The young lads were excited and tense about what they were experiencing. "When our gang heard that there was shooting and the din of battle somewhere, we just went to see; we did not understand to be afraid." 16 The boys drifted in groups around Tampere, and during these tours they saw the brutality of war. For the boys between the ages of 7 and 14, the streets and quarters had become familiar during the time before when they had worked as errand boys, newspaper vendors and shoeblacks. These dead-end jobs offered the possibility for workingclass boys and girls to earn money. This was a typical phenomenon in all cities.

During the war, boys wanted to continue their way of life. Paavo Johannes was 11 years old in 1918, and about 50 years later, he reminisced about a walk he had taken around the town during a battle. He had seen two young, about 15- or 16-year-old Red Guards losing their lives. Paavo Johannes recounted that all that had happened and every thing he had

${ }^{13}$ I define the Red orphans' generation as including those children whose fathers had fought on the Red side. This refers to the experience of belonging to a population group that had lost the war.

${ }^{14}$ Opettajain lehti (Teachers Magazine), Kasvatus ja koulu (Upbringing and School), Alakansakoulu (Lower Primary School), Suomen Kasvatusopillinen aikakauskirja (Finnish Pedagogical Journal).

${ }^{15}$ Marianne Junila, "War through children's eyes," in Tepora \& Roselius (2014), 230-53.

${ }^{16}$ Tampere University, Folklife Archives (hereafter FA), Tampere Political Heritage (hereafter TPH), Ojala, Otso (1911) 6358; Järvinen, Toivo Vihtori (1908) 6400. 
seen during the Civil War returned to his mind much later. "As a child, all things did not come to mind. The events were out of my mind for a long time and now these memories begin to come back again. There is now more time to think." ${ }^{17} \mathrm{He}$ contemplated years later that when he had processed his experiences with a child's brain, he had not had nightmares. "I thought it belongs to the rhythm." 18 Urpo said the same. "It no longer feels like anything, when you see people dying. The Guard bayonetted a person to death. You got used to it."19

When the Battle of Tampere began, people had to escape from their homes and try to find shelter in churches, schools and the basements of public buildings. Toini, born in 1908, remembered when shelling got closer and her family was woken up in the middle of the night and told to leave to find shelter. When Toini ran with her family, they heard shooting quite close by. Toini describes her experiences in the following words: "Strange that I was not afraid. I did not feel any fear. The adults were afraid. It was exciting." ${ }^{20}$ Toini and her family stayed in a shelter in a cellar near her home for two weeks. ${ }^{21}$ The noise of the artillery, street fights and the whistling of shells could be heard inside the shelters and cellars. ${ }^{22}$ Nevertheless, young people could not resist leaving the shelters. They would leave at dusk for the town center in order to see what was going on. ${ }^{23}$ The huge fires, the blackened and deserted houses and the lines of prisoners remained in their minds after the battles. "The night when the town was finally captured, we children, were in a cellar and saw the great fire of Kyttälä. It felt gloomy."25

After the battles ended, the massive damage to the town was revealed. More than a hundred buildings had been destroyed. ${ }^{26}$ One mother commented that children are so used to seeing dead bodies that it no longer feels like anything. ${ }^{27}$ First, families wanted to see if their own homes had

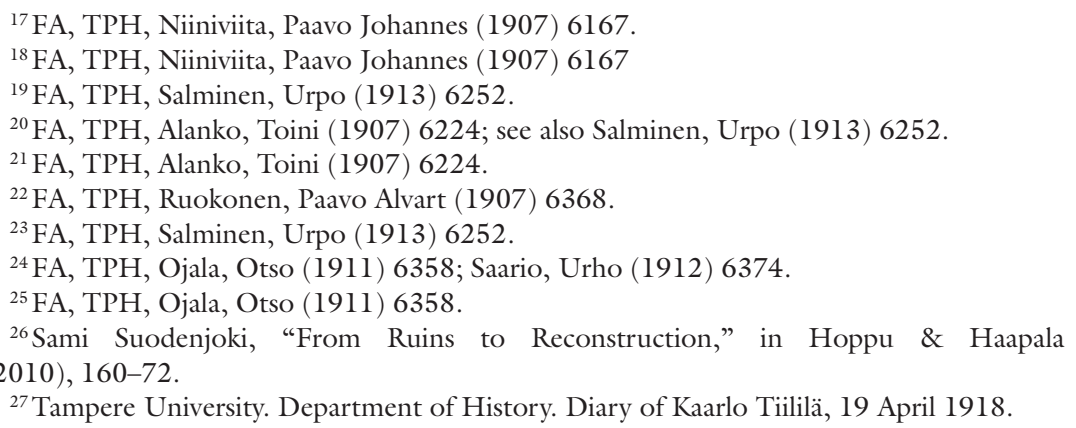


been damaged or burnt down. Parents walked with their children through the town. The children were thus exposed to the destruction, to homes where everything had been turned upside down, to windows, ramparts and stoves destroyed and furniture broken. On the way home, there were dead bodies, shattered carriages, horses lying on the ground and the smell of smoke. The prisoners gathered at the Market Square stuck particularly in the children's minds. ${ }^{28}$ Several decades later, Otso described thoughts he had had at the time: "I did not feel any fear of these dead people and dead horses." ${ }^{29}$

The battle was over but it would be a long way back to peace and a normal life. Paavo Alvart describes his experiences during the final stages of the war:

Two fallen Red Guards were lying Under our window. At the Central Square,
prisoners were left standing for the whole day. We heard that the aim was to
shoot them at the Central Square with machine gun fire. Some of the prisoners
were taken to the old Russian barrack area. Waking up in the middle of the
night was terrible. My mother had blankets and pillows around her head to
mute the sounds of execution shots. My father tore his hair out. It was terrible
even from a child's eyes to think about what was happening when the shots
resounded. In the morning at $20^{\prime}$ 'clock the execution shots were heard. They were
indelibly stamped into my mind at that time. That lasted the whole summer.

When people spoke of their experiences, the common and repetitive theme was their view of fear. Why they, as children, were not afraid, why they did not understand to be afraid? Trauma psychologist Kirsi Peltonen has analyzed in her research children's and adolescents' unique way of meaning making and handling violent situations. As she writes, each developmental stage offers both protective self-healing processes and vulnerabilities. Hence, the lack of full understanding of frightening events might, in this case, have protected the children in traumatic situations. ${ }^{31}$ The chain of events was remembered in very detailed ways, and it proves how

\footnotetext{
${ }^{28}$ FA, TPH, Ojala, Otso (1911) 6358; Saario, Urho (1912) 6374; Järvinen, Toivo (1908) 6400; Lindholm, Eino (1912) 6436.

${ }^{29}$ FA, TPH, Ruokonen, Paavo Alvart (1907) 6368; Ojala, Otso (1911) 6358, Niiniviita, Paavo Johannes (1907) 6167.

${ }^{30}$ FA, TPH, Ruokonen, Paavo Alvart 6368; also Kolinen, Elsa (1903) 6898.

${ }^{31}$ Kirsi Peltonen, "Children and Violence: Nature, consequences and interventions focuses on mental health and social relations of children exposed to violence" (PhD dissertation: University of Tampere, 2011), 14.
} 
strong these childhood experiences during the war had been. The war changed normal daily routines completely. The sounds of fighting, the walking routes, the people on the streets and the passers-by were decades later described in detail. The memories are sharp and they concern, for example, the houses and streets where shooting was witnessed, where the dressing station was situated, where guns and ammunition were placed and where dead bodies were lying. The descriptions are present in memories as detailed visions. ${ }^{32}$

During the days, weeks and months after the battle, boys and girls were closely involved in the life of the town around them. The boys' activities in the town and their curiosity concerning exceptional circumstances proved that the war was also an adventure. The young people watched what was happening around them, and they followed the model they got from adults. When dead bodies were picked up, boys checked the pockets of the victims and collected what they thought might be profitable. Adults would chase the children away at once when they saw them, but there were always opportunities in such chaotic circumstances. ${ }^{33}$

The children had been involved in dangerous and traumatic situations, and they were entrusted with more responsibility than in ordinary circumstances. Paavo Johannes had followed his father to see the damage to their neighborhood only to be met with White troops carrying out inspections. In this situation, Paavo Johannes' father was aimed at with a rifle, after which he was arrested and taken away. Paavo Johannes ran to his mother who told Paavo Johannes to run after his father and find out where he had been taken. ${ }^{34}$ The children wandered with their mothers and relatives near the cemetery area looking for their loved ones among the heaps of dead bodies. Mothers sent children to prison camps to carry food to their fathers, relatives or neighbors. This job was easier for children because the guards at the camp were not so aggressive towards them. ${ }^{35}$ The fallen or executed father is often mentioned in the memories of the respondents, and after the father's death came anxiety about the mother. Vieno, born 1914, explained that she and her siblings would not allow their mother to

\footnotetext{
${ }^{32}$ For example: FA, TPH, Niiniviita, Paavo Johannes (1907) 6167.

${ }^{33} \mathrm{FA}, \mathrm{TPH}$, Salminen, Urpo (1913) 6252.

${ }^{34}$ FA, TPH, Niiniviita, Paavo Johannes (1907) 6167; Ruokonen, Paavo Alvart (1907) 6368.

${ }^{35}$ FA, TPH, Salminen, Urpo 6252; Ruokonen, Paavo Alvart (1907) 6368.
} 
disappear from their sight. Children shouted after their mother: "Don't go, they will also kill you." 36

Although the war had made death a daily affair, the children realized that the way the bodies of the Red troops were treated was not right or acceptable. Sorrow, remembrance and respect for the dead also belonged to the losing side. About a year after the end of the Civil War, in May 1919, a group of girls and boys wanted to remember the Reds who had died in the war. The children knew the location of a mass grave and put a red cloth they had purchased there as a flag. It was the children's own idea, for they felt the need to commemorate the grave. They also waited to see if anyone would take their flag away. Nobody came. ${ }^{37}$

\section{At Home: Hunger, Cold and Bitterness}

For the children of the Reds, the Civil War and its aftermath left them with the sense that no one cared what happened to their families and that no one would help them. Otso was seven years old in 1918 and he retrospectively analyzed his feelings: "There was no pity towards the Reds. The society did not think about them. It was trying to fall silent. Keep quiet. The beaten were left alone to lick their wounds. Those who had stayed alive tried to lick wounds." 38

Bitterness towards White winners and the whole of Finnish society can be found in Otso's speech. The bitterness, however, was an emotion from which the children of the Reds should have been saved and helped to overcome. The state authorities understood as early as the spring 1918 that children and young people had an important role to play in building a new independent Finland. It was the duty of the Finnish nation to care for the Red children and educate them to be "good citizens." The most important task would be to teach them to love their fatherland. ${ }^{39}$ The children's experience after the war that led them to feel that no one cared about them meant that it was difficult to learn to love their fatherland and to grow up to be patriotic citizens.

\footnotetext{
${ }^{36}$ Finnish Labour Archives (hereafter FLA), The Commission of Finnish Labour Tradition (hereafter CFLT) 252/1100; also FA, TPH, Kolinen, Elsa (1903) 6898.

${ }^{37}$ FA, TPH, Niiniviita, Paavo Johannes (1907) 6167; see also Alanko, Toini 6224.

${ }^{38} \mathrm{FA}$, TPH, Ojala, Otso (1911) 6358.

${ }^{39}$ Mervi Kaarninen, Punaorvot 1918 (Helsinki: Minerva, 2017), 12-42.
} 
In post-1918 Finland, there were two categories of orphans. White orphans were treated as the children of national heroes who had saved Finland (the fatherland) from bolshevism. The National Board of Social Welfare organized the support of White families through a statutory pension. But while Whites had the right to pensions, the Reds had to apply for municipal poor-relief funds in order to stay alive. The pensions for White war widows and orphans were understood to be a hard-earned winners' right. After the Great War in Europe in countries like Britain, France and Germany, pension schemes were created for the war widows and orphans. ${ }^{40}$ In Finland, this kind of war-widow pension scheme was out of the question for the red widows and orphans during the years that followed the war. The Red widows ultimately received a pension granted by the Finnish government, and the status of war widow, only in 1943, 25 years after the end of the Civil War. ${ }^{41}$

Based on statistics, most Red families were poor and would have needed societal aid. It was understood that without societal intervention, these families would starve to death, so the state began to organize relief work to help Red families suffering from hunger and cold. The average age of children, in the whole country, who had lost a father, was seven years, and there were, on average, three children under the age of 15 in such families. For the Red widows, it was difficult to find jobs because of the prejudices many employers held towards them. If a mother did find a job, the daycare for small children caused problems. ${ }^{42}$ Additionally many families were homeless because of the damages incurred in the war. Many families had been housed in company flats, and they often had to move due to the death of the father. In addition, many house owners were unwilling to rent flats to Red families. ${ }^{43}$

${ }^{40}$ Michael Lanthier, Women Alone: War Widows in Third Republic France, 1870-1940 (Burnaby: Simon Fraser University, 2004); see also Angela Smith, Discourses Surrounding British Widows of the First World War (London: Bloomsbury, 2013), 71, 77-88; Caoimhe Nic Dháibhéid, "Schooling the National Orphans: The Education of the Children of the Easter Rising Leaders," Journal of the History of Childhood and Youth 9:2 (2016), 261-73.

${ }^{41}$ Juho Partanen, "Punaleskien eläkkeet 1943," in Wars, Internees and the Transition to the Postwar Era, ed. by Lars Westerlund (Helsinki: Kansallisarkisto, 2010), https://arkisto.fi/ uploads/Julkaisut/monografiat/Internoidut_Naytto.pdf, accessed 24 August 2020.

${ }^{42}$ Suomen sotaorvot, tilastollinen selonteko. (A statistical account of war orphans in Finland). Les enfants abandonnés par suite de la guerre 1919. Statistique pour la Finlande, 375-95.

${ }^{43}$ Suodenjoki (2010), 160-72. 
The Finnish National Board of Social Welfare reacted quickly after the war by planning an operation to transfer children of the Reds to White homes in agrarian areas where foodstuffs were more available than in urbanized areas. The foster parents were supposed to raise children to appreciate the independent fatherland and its values. The transfers were seen as a means to save children from warfare, hunger and cold, as well as a socialist upbringing. The Red mothers were stigmatized as a social threat that could not be trusted with such an important task as bringing up the new generation. ${ }^{44}$ This plan proved how suspicious the state authorities and social workers were towards the Red mothers' ability as parents. ${ }^{45}$ However, this operation had connections to the wider question of child transfers and relocation in Europe after the Great War. During and after the war, tens of thousands of children were moved from Central Europe to areas that had suffered less during the war, such as Denmark and Sweden. Carried out until 1924, the transfers of children incorporated humanitarian and political motivations. ${ }^{46}$

Charitable organizations took on an important role in trying to influence people's opinions and getting help for the orphaned children and widows who found themselves in the middle of a catastrophe. The organizations published appeals filled with emotional rhetoric, and in which charity and concrete aid were combined with Christian love and love of the fatherland. It was felt that it would be in the fatherland's interest to help the Red children, children who should not be punished or rejected for their father's wrongdoings, and who should be forgiven their parents' sins. ${ }^{47}$ In some appeals it was recommended that Finland should give up foreign missions so that the resources could be used for "local pagans." 48 Using the concept of "pagan" in this context meant that the Red widows and orphaned children were seen as objects needing missionary and educational aid.

To get the poor relief, the Red widows were obliged to accurately explain the economic circumstances of the family. The local poor-relief

\footnotetext{
${ }^{44}$ Tiina Lintunen, “Women at War," in Tepora \& Roselius (2014), 201-29.

${ }^{45}$ Kaarninen (2017); Komiteanmietintö 1919:11. V. 1918 kapinan aiheuttamain turvatonten lasten huoltokomitea (Helsinki, 1919).

${ }^{46}$ Monika Janfelt, "Stormakter i människokärlek: Svensk och dansk krigs-barnshjälp," (PhD dissertation: Åbo Akademi, 1998); Donson (2010), 170-2.

${ }^{47}$ Paulus, "Rientäkää auttamaan kovaosaisia lähimmäisiämme," Huoltaja 7:14 (1919), 208-10.

${ }^{48}$ Iida Yrjö-Koskinen, “Olisiko mahdollista?” Suomen Nainen 25 January 1919, 33-4.
} 
authorities had the right to decide what kind of assistance they gave: whether it be financial assistance, food aid or firewood. The authorities could encourage or even force the mother to place her children in foster homes or children's homes so that she could go to work more easily. ${ }^{49}$ If the poor relief was granted, the families would be under state control and the authorities could make inspections of homes to check on how the poor relief was being used. The state, via the National Board of Social Welfare, nevertheless understood the difficult situation these families found themselves in and granted supportive regular governmental subsidies to municipalities and organizations engaged in helping Red families. This system was the first step towards promoting harmonization and represented a significant investment by a heavily indebted country. ${ }^{50}$ According to earlier legislation, local poor-relief authorities were obliged to help only children and young people under 15 years of age. Those 15-years-old and older were supposed to support themselves and were also expected to contribute to the living costs of their family. The upbringing and education of Red orphans to become good and patriotic citizens were seen as such important goals in postwar Finland that the ministry of social welfare decided to allocate state aid for the vocational education of Red orphans up until their 17th birthday, or their 21st, if they could show that they were in a vocational school or were training for a job. ${ }^{51}$

In the reports and memories of the Red widows and orphans, these kinds of relief and the state's role in granting subsidies to municipalities have not been mentioned. One reason for this could be the humiliating character of the poor relief. On the other hand, this exemplifies the effects the experience and the circumstances produced on people's minds. The subsidies which families received were very small, and this contributed to the feeling that no one actually helped or really cared.

Life for the Red families was hardest in the summer and autumn of 1918 , as well as in the winter of 1919. Since the summer of 1917, town dwellers had suffered from food shortages and even hunger. ${ }^{52}$ The hunger forced inhabitants to take action, and children were particularly active and self-motivated in this difficult situation. Urpo recounted that when he

\footnotetext{
${ }^{49}$ FA, TPH, Kolinen, Elsa (1903) 6898; Kaarninen (2017).

${ }^{50}$ Komiteanmietintö 1919:11. V. 1918 kapinan aiheuttamain turvatonten lasten huoltamisesta (Helsinki, 1919).

${ }^{51}$ Mervi Kaarninen, “The long War of the Orphans,” in Hoppu \& Haapala (2010), 174-85.

${ }^{52}$ For the food shortage see Pertti Haapala, "Expected and Non-expected Roots of Chaos: Preconditions of the Finnish Civil War," in Tepora \& Roselius (2014), 21-50.
} 
witnessed a horse fall in battle, young boys were asked to cut the horse's flesh into small pieces. The flesh was to be used at home to help with the food shortage.$^{53}$ During those difficult times, children were forced at an early age to help their mother. ${ }^{54}$ First, the mothers sent young boys and girls after midnight to queue at local shops, hoping to get milk and flour. Then children began to develop their own strategies to relieve their hunger through begging. The same groups of boys that had gone around town during the battles made begging trips to the countryside in the areas surrounding Tampere. ${ }^{55}$ Children from ages 10 to 12 took part in even two-week-long begging trips on foot. They did not ask permission or even tell their parents about their plans. The rumors that there were foodstuffs such as bread, flour and milk available in the farmhouses in the countryside inspired the begging. The societal disorder and food shortage lay at the root of the begging and made it acceptable.

The begging was not limited only to boys since girls also went begging. Children would not only go from door to door but would also beg in trains, marketplaces and restaurants. During the begging trips, the children learnt how to survive in difficult circumstances. In the life stories, the begging trips that were made have been described as adventures, reflecting both the experiences of the time and the later narration of the events. The young boys slept in hay barns, fished in order to get food and stole, if it was the only way to stay alive.$^{56}$ With regard to children's war experience, Nazan Maksudyan has proven how children were partakers, actors and witnesses to the political actions of the Ottomans. They were active agents as soldiers, wage earners and farmers. ${ }^{57}$ The begging of the children of Red families can equally be understood as one form of resistance and as proof of children's own agency. This resistance and agency drew from the contemporary circumstances and the White winners' behavior and can also be interpreted as supportive of the mother, the family and the defeated side. ${ }^{58}$

\footnotetext{
${ }^{53}$ FA, TPH, Salminen, Urpo Olavi (1913) 6252.

${ }^{54}$ FLA, CFLT 252/1100.

${ }^{55}$ FA, TPH, Kuusinen, Urpo (1907) 8357; Niiniviita, Paavo Johannes (1907) 6167; Ojala, Otso (1911) 6358; FLA, CFLT 252/1100.

${ }^{56}$ FA, TPH, Kuusinen, Urpo (1907) 8357; Niiniviita, Paavo Johannes (1907) 6167; Ojala, Otso (1911) 6358; FLA, CFLT 252/1100.

${ }^{57}$ Maksudyan (2019), 11-15.

${ }^{58}$ Susan A. Miller, "Assent as Agency in the Early Years of the Children of the American Revolution," Journal of the History of Childhood and Youth 9:1 (2016), 48-9; see also Ville
} 
In the autumn of 1918, newspapers wrote that thousands of child beggars were traveling around Finland in search of sustenance. Children's begging had become systematic and professional and the authorities tried to put a stop to it. In Finland after the Civil War, as elsewhere in nineteenth- and early twentieth-century Europe, the begging became associated with wandering children and juvenile delinquents. ${ }^{59}$ Begging went against all the principles of a civilized state. In the autumn of 1918, various associations, with government support, established shelters for wandering child beggars. Newspapers wrote about their living conditions and urged citizens to do their best to discourage begging. ${ }^{60}$

During their begging trips, children learnt how to behave to get the best possible result. Sometimes boys and girls had some bric-a-brac such as buttons, ribbons, needles, pins and shoelace to sell. It was easier to arrive at a farmhouse and ask if buttons or needles were needed. Paavo Johannes described his begging tours as follows: "We wandered to farmhouses. The instinct of the young boy. First we gave the farmer and his wife a chance to express their opinion (on the war and on the Reds). We understood that we would receive more food if we agreed with the house's owners. We became plotters. It provided food." ${ }^{61}$ This case exemplifies the emotional frontier where the children lived and how they had to learn to act on the different frontiers. ${ }^{62}$ Paavo continued his story: "Sometimes we even received from the croft or cottage owner an invitation to sit down at the table." 63

\section{The Classroom as an Emotional Community}

After the war, the children of the Reds had to return to school. Educators and state authorities had the strong conviction that primary school could save the children for the nation. All the tragic consequences of the war

Vuolanto, "Experience, Agency, and the Children in the Past: The Case of Roman Childhood," in Children and Everyday Life in the Roman and Late Antique World, ed. by Christian Laes \& Ville Vuolanto (New York: Routledge, 2018), 11-21.

${ }^{59}$ Miranda Sachs, “'A Sad and Odious Industry': The Problem of Child Begging in Late Nineteenth Century Paris," Journal of the History of Childhood and Youth 10:2 (2017), 188-205.

${ }^{60}$ Kaarninen (2017).

${ }^{61}$ FA, TPH, Niiniviita, Paavo Johannes (1907) 6167; FLA, CFLT 252/1100.

${ }^{62}$ Stephanie Olsen, "Introduction," in Olsen (2015), 1-10.

${ }^{63}$ FA, TPH, Niiniviita, Paavo Johannes (1907) 6167; FLA, CFLT 252/1100. 
were encountered in the classroom, which became the scene of contradictory emotions. The fatherland of the primary school teachers was unconditionally the Finland of the White winners. ${ }^{64}$ The pupils knew that the teachers were on the winners' side. ${ }^{65}$ The re-education of the Red children to become patriotic citizens of the new independent Finland was nevertheless felt to be possible through the help of primary school and civic education. In the spring of 1918, even before the official end of the Civil War, the Teacher's Magazine asked: "What must be done so that our nation can be saved from doom. The compulsory education act must be carried out, whatever the cost. Every child has the right to a good upbringing." $" 66$

The schools had been closed during the war, but after the twomonth break, they were re-opened in mid-April. ${ }^{67}$ Some teachers began the school year by enquiring about the pupils' circumstances at home and asking about their father's participation in the war. Some pupils happily gave answers, and many were proud that their father had belonged to the Red Guard. ${ }^{68}$ Then again, Toini said that those children whose fathers had died or were in prison were shy and thought it better to be silent. ${ }^{69}$ Some of the pupils' answers confused teachers. Vieno, for instance, answered: "My father was shot as a rebel. I don't have a father." Children also repeated words and phrases that they had heard in the adults' conversations. ${ }^{70}$

Good judgment was called for from teachers when welcoming to school those children who had lost their father or mother, and those

${ }^{64}$ Kansakoulun lebti 36:13-18 (1918), 158-63.

${ }^{65}$ FA, TPH, Alanko, Toini (1907) 6624. Tampere employed about 130 primary school teachers, and it is obvious that their Whiteness as well as Redness could have different shades. After the war, in Finland 92 primary school teachers were accused of supporting the Reds, which meant 1.6 percent of total primary school teaching staff. Mervi Kaarninen, "Kansakoulu, kansakunta ja tottijärveläiset," in Työpäestö ja kansakunta, ed. by Raimo Parikka (Helsinki: Työväen historian ja perinteen tutkimuksen seura, 1997), 179-80; Jukka Rantala, Kansakoulunopettajat ja kapina: vuoden 1918 punaisuussyytökset ja asema paikallisybteisössä (Helsinki: SKS, 2002).

${ }^{66}$ O. K., "Mitä on tehtävä?” Opettajain lehti 13:6 (1918), 67. The discussion continues in: K. K. M, “Näkökulmia,” Opettajain lehti 13:9 (1918), 98-9; E. Kangas, “Mitä on tehtävä?” Opettajain lehti 13:10 (1918), 108-9.

${ }^{67}$ About school work during the Civil War in Tampere see Junila (2014), 230-53.

${ }^{68} \mathrm{FA}$, TPH, Salminen, Urpo (1913) 6252; Syrjä, Unto (1910) 6389-90.

${ }^{69} \mathrm{FA}, \mathrm{TPH}$, Alanko, Toini (1907) 6624.

${ }^{70}$ FLA, CFLT 336/31/1771. 
children whose fathers were waiting for their sentences at the prison camps. When the hostilities were over, for example, one of the Tampere primary school teachers wanted to get pupils back to school as soon as possible, so she went around pupils' homes to pick them up. Her aim was to prevent children from seeing all the ruins and destruction in the city, as well as to keep them from hearing the voices of drunken Whites celebrating victory. ${ }^{71}$ In the reminiscences of the children, school teachers are often remembered positively, and many teachers were appreciated for their warm attitude towards fatherless children. ${ }^{72}$ Leo's father died in the prison camp and, in addition, his two older brothers had fought in the Red Guard. Leo remembered his school time: "The school was easy for me. I was the best pupil in my class [...] I was encouraged to go to the secondary school but I had to work and give my earnings to my mother. At the school I sat at the first desk. I was given a nickname by the other pupils as the teacher's 'blue-eyedboy.' If I did not know my homework it shamed me."73

According to the harmonization politics of the state and the National Board of Education, teachers were required to have societal awareness and knowledge of human nature. Their duty was to equalize class distinctions, so they had to try to bring the children from different social classes together. Despite their own world views, the teachers were expected to behave sympathetically and without bias towards the Red children. Teachers were allowed political opinions but not agitation. ${ }^{74}$ The situation in Tampere was special due to the fact that in the local elections at the end of 1918 the social democrats had won a majority in the city council. Thanks to municipal democracy, the social democrats got their delegates onto the municipal school board to make decisions on school affairs. These town councilors brought some

${ }^{71}$ Lyyli Friman, "Esimerkillinen opettaja: Muistelmia opettaja Maria Laurilasta," Tammerkoski 15:7 (1953), 209-10.

${ }^{72}$ FA, TPH, Alanko, Toini (1907) 6624; Kuusinen, Urpo (1909) 6155; Niiniviita, Paavo Johannes (1907) 6167; Ojala, Otso (1911) 6358; Haavisto, Elma (1907) 6250.

${ }^{73} \mathrm{FA}$, Laakso, Leo (1914) Y 4315.

${ }^{74}$ Kouluhallituksen arkisto (KA, Arcives of School Adminstration). Tampereen piirin kansakoulun opettajiston piirikokouksessa 22.-23.9.1919; Hämeenlinnan tarkastuspiirin ptk:t 1.-2. Kesäkuuta. P. Korppoo: Opettajain suhtautumisesta lasten vanhempiin; Vuosikatsaus Savonlinnan piirin kansakouluihin 1918-1919. J. F. Cantell, Mihin pitää kansakoulun kasvatuksen ja opetuksen yleensä pyrkiä; Kansakoulun lebti 36 (July/September 1918), 158-63. 
understanding of the circumstances of Red children, and especially of Red orphans, to the decision-making.

Poverty was present in the classrooms and caused feelings of indignity. Children were divided into Reds and Whites and into the wealthy and the poor. These divisions expressed the existence of contradictions. The party divisions were sharp within children's communities just like in the classrooms and yards, as Toini narrates: "Children began to build barriers themselves during the war and after it. There were Reds' kids and butchers' $^{75}$ kids. I was a butcher's kid and my friend was a house owner's daughter. We were Whites and the washer's daughter called us butcher's kids while we called her a servant's brat."

The children from poor families, and especially Red orphans, received shoes and clothes via the primary school as poor relief. These clothes were seen as signs that identified children and were experienced as labels stamped by the Whites. ${ }^{77}$ In order to get these shoes, coats and trousers for the children, the teacher had to write a certificate of indigence. This was one way in which the local poor-relief and school authorities tried to organize help for the poor and needy families. For the children, this wellmeant procedure caused feelings of humiliation and shame. ${ }^{78}$ It irritated them that the clumsy black shoes and the color and quality of the textiles revealed the clothes' origin. The clack of clogs served to signal that Red children were walking nearby. The boys were picked on when they had to come to school in their sisters' shoes with white socks. Older boys had to use men's old shoes that were too big for them. ${ }^{79}$ Most of the primary school pupils came from working-class families but the disparities in wealth caused segregation. It made a great difference if both parents were alive and the father had a permanent job. ${ }^{80}$

\footnotetext{
${ }^{75}$ The Whites were named collectively as "butchers," which was an insulting name for white soldiers denoting cruelty and inhumanity. The name "butcher" was also used to mean an executioner.

${ }^{76} \mathrm{FA}$, TPH, Alanko, Toini (1907) 6624.

${ }^{77} \mathrm{FA}, \mathrm{TPH}$, Ojala, Otso (1911) 6358.

${ }^{78}$ About humiliation and shame in the classroom, see Ute Frevert, The Politics of Humiliation: A Modern History (Oxford: Oxford University Press, 2020), 79-82.

${ }^{79} \mathrm{FA}$, TPH, Ojala, Otso (1911) 6358.

${ }^{80}$ FLA, CFLT 336/31/1771.
} 
The primary school wanted to intrude into pupils' homes and to bring parents into the sphere of instruction as well. ${ }^{81}$ Pedagogues thought that the parents had failed as educators of their children. The National Board of Education wanted to reduce the contradictions between teachers and parents through home and school interaction. When the parents were unable to teach the idea of the fatherland, it became Society's duty to organize what the parents neglected. Teachers experienced special difficulties in meeting socialist parents and co-operating with them. They thought that the homes tried to destroy all that the school aimed to construct. All the official expectations were therefore difficult to fullfil in practice. ${ }^{82}$

The primary school inspectors gave practical advice on how to organize the interaction between the home and the school. The primary school teachers were encouraged to invite parents to school and to participate in school celebrations. These events were given an important role as a tool for the emotional education of pupils during the 1920s. The Independence Day and the Kalevala Day ceremonies strengthened the national identity and the idea of the fatherland. Teachers were advised to organize Christmas pageants as unforgettable and emotional events. The Christmas tree at a school was seen as being especially important for those children who could not have one at home where Christmas was not given such a great importance. The school was supposed to offer Christmas spirit to the children of poor homes. Additionally, with these events, it was possible to advise mothers on how to organize Christmas at home. ${ }^{83}$ A primary school teacher described the idea of the Christmas tree and how it could create a feeling of warmth and sensitivity in children: "The Christmas tree in our common classroom, which is the temple of our work, pushes like a loving mother's gaze directly into the depths of the heart. ${ }^{84}$ The Mother's Day festivities in the early 1920s became another area of responsibility for primary school teachers. Motherhood was seen as a

${ }^{81}$ Elhti [Eemeli Etelälahti], "Koti ja koulu. Kotikasvatusta kohentamaan II,” Kansakoulu 1:27 (1929), 482-3.

${ }^{82}$ Aukusti Salo, "Koulun tehtävä isänmaallisen hengen kasvattamisessa," Kasvatus ja koulu 8:6-7 (1922), 146-53; Paavo Virkkunen, "Maailmansodankokemukset ja tulevaisuuden kasvatus," Kasvatus ja koulu 4:9 (1918), 279-84.

${ }^{83}$ J. L., "Kuusijuhlat kouluharrastuksen herättäjinä," Opettajain lehti 14:48 (1919), 615.

${ }^{84}$ Maalaisopettaja, "Kuusijuhlat," Opettajain lehti 19:51-2 (1924), 950-1. 
woman's real nature and the most important task in bringing up the next generation of the Finnish nation. A special meaning was attributed to Mother's Day as a national day dedicated to Finnish mothers as the hearts of homes and heroes. ${ }^{85}$

An important milestone on the path towards harmonization was the universal compulsory education act, which came into force in 1921. The new legislation brought children between the ages of 7 and 14 within the sphere of compulsory studies. The law entitled everyone to receive education free of charge, regardless of gender, language or social class. This meant that children of all social classes met in the classroom. ${ }^{86}$ This was a big investment for a poor country. In the 1920s and 1930s, the Finnish primary school emphasized the patriotic values of the nation state. The new national curriculum highlighted history, religion, the agrarian way of life and patriotism. Cleanliness and obedience were also important areas of instruction. Primary school teachers intruded into pupils' homes through hygiene and health inspections, thus bringing households into the sphere of health education as well. ${ }^{87}$

The lines of division that separated school pupils, as well as the societal contradictions and the experience of bitterness that persisted, surfaced as resistance. The attitudes became apparent in the classroom community and outside the school during free time. As Paavo Johanes concluded: "Class divisions prevailed among the children who were divided into Reds and Whites. It was seen as natural. The war continued among the children and reflected the previous attitudes within the families. It shaped relationships among the children." 88

Eino described classroom feelings that emerged when the teacher began to speak about patriotism. The boys gave the teacher the bird. Four fingers

\footnotetext{
${ }^{85}$ On motherhood, see Johanna Valenius, Undressing the Maid: Gender, Sexuality and the Body in the Construction of the Finnish Nation (Helsinki: SKS, 2004), 111; "Äitienpäivää viettämään," Opettajain lehti 16:16 (1921), 211; “Äitienpäivää viettämään," Opettajain lehti 17:17 (1922), 196; “Äitienpäivää viettämään,” Opettajain lehti 18:19 (1923), 298-9.

${ }^{86}$ Jukka Rantala, "The Political Ethos of a Model Citizen: Ensuring the Correct Political Attitude of Elementary School Teachers during the First Decades of Finland's Independence," in Nordic Lights: Education for Nation and Civic Society in the Nordic Countries, 1850-2000, ed. by Sirkka Ahonen \& Jukka Rantala (Helsinki: SKS, 2001), 153-72.

${ }^{87}$ Pauli Arola, “Tavoitteena kunnon kansalainen: Koulun kansalaiskasvatuksen päämäärät eduskunnan keskusteluissa 1917-1924," (PhD dissertation: University of Helsinki, 2003); Saara Tuomaala, Työtätekevistä käsistä pubtaiksi ja kirjoittaviksi: Suomalaisen oppivelvollisuuskoulun ja maalaislasten kobtaaminen 1921-1939 (Helsinki: Otava, 2004), 63-6, 262-83.

${ }^{88}$ FA, TPH, Niiniviita, Paavo Johannes (1907) 6167.
} 
were put in the mouth and then booing begun. Eino stated that this kind of a speech was a waste of time. The patriotic celebrations at the school did not therefore evoke only warm emotions towards the fatherland, which was their aim. ${ }^{89}$ In the Independence Day celebration, the boys refused to sing Paavo Cajander's patriotic song "Raise a toast to the fatherland" which contains the words: "One power is hidden in the heart. That power is pure and holy." 90 The lyrics describe love for the sacred fatherland, thus setting powerful emotions alight. The song emphasizes the feeling in such a way that one is prepared to die, overcome dangers and starve for the fatherland. The refusal of the boys to sing caused the teacher to lose his temper, put his foot down and roar, "you are like your fathers, Red refugees in Russia." Instead, the school children sang mocking songs of the war hero and commander in chief of the White army, General Mannerheim. ${ }^{91}$ Eino also said that they had had a singing exam where the pupils were allowed to decide for themselves which song they would sing. Eino decided to sing an old Finnish labor movement song (Workers' March). He sang the whole song after which the teacher expressed his opinion through giving him a low grade for his performance. ${ }^{92}$

Just as with patriotic songs, history teaching also produced resistance among the Tampere schoolboys. History was among the most important subjects in the curriculum since it was connected with a patriotic upbringing and the will to defend the nation. ${ }^{93}$ In one of the textbooks, there was a picture with the text "the Jäger of the War for Freedom." crossed out the text and wrote instead, "the Finnish Butcher." This textbook, which caused debate in the newspapers, described the Civil War one-sidedly as a war of liberation and underlined the savagery of the

${ }^{89}$ FA, TPH, Ruokonen, Paavo Alvart (1907) 6368.

${ }^{90}$ Paavo Cajander, Maljan esitys isänmaalle. Composition by Jean Sibelius.

${ }^{91}$ FA, TPH, Haavisto, Elma (1907) 6250.

${ }^{92} \mathrm{FA}, \mathrm{TPH}$, Lindholm, Eino (1912) 6436.

${ }^{93}$ See Aimo Halila, Suomen kansakoululaitoksen historia IV (Porvoo: WSOY, 1950), 178-82; Tuomaala (2003).

${ }^{94}$ The Jägers were Finnish volunteers in the German army in the World War I; they formed a key element in the White Army in 1918. 
Reds. ${ }^{95}$ Paavo Alvart analyzed his feelings: "It produced resentment towards the upper classes; we were keen men of the resistance." 96

The war continued in the children's games, and the Battle of Tampere was fought again in the home yards and nearby forests. ${ }^{97}$ The pupils did not fight in the school yards during the breaks; and there was a gentlemen's agreement that the teachers would not interfere in the fights that occurred on the way to school..$^{8}$ Several "minor" Red Guard groups were established around Tampere, and the boys formed their own armies with companies and commanders. ${ }^{99}$ The young boys from 5 to 12 paraded with, in their belts, wooden swords with metal points. They wandered through the city seeking the traces of battle; they also prepared gunpowder mixtures, hand grenades and organized fire fights. All this was dangerous and injuries happened. ${ }^{100}$ For the children, the war games had replaced the game of cops and robbers. In a similar manner, Andrew Donson describes German children's war games during the Great War, when the boys held battles complete with uniforms, iron crosses, pails for cannons and battery walls. ${ }^{101}$ In Tampere, one way to express feelings towards people who were known as Whites was to annoy them by throwing stones on their roof and then running away. ${ }^{102}$ The resistance of schoolboys became concrete when the memorial ceremony for the Battle of Tampere and the unveiling of the Statue of Freedom to the honor of the White winners was organized in Tampere in April 1921. The boys named this festivity the "butchers' market." A group of schoolboys who worked as shoeblacks were viewing this ceremony angrily with tears in their eyes. They stood crying by themselves with their fists in their pockets, but after the ceremony, the boys began an attack on the statue by throwing shoe polish cans at it. ${ }^{103}$

${ }^{95}$ Suomen Sosialidemokraatti 12 January 1920 \& 28 October 1920; Opettajain lehti 15:42 (1920), 569-70; see also Oona Ilmolahti, Eheys ja ennakkoluulo: Työväenyhteisön ja kansakoulunopettajiston subde Helsingissä sisällissodasta 1930-luvulle (Helsinki: Työväen historian ja perinteen tutkimuksen seura, 2017), 179-83.

${ }^{96}$ FA, TPH, Ruokonen, Paavo Alvart (1907) 6368.

${ }^{97} \mathrm{FA}, \mathrm{TPH}$, Lehtinen, Kalle Johannes (1910) 6242.

${ }^{98} \mathrm{FA}, \mathrm{TPH}, \mathrm{Lindholm}$, Eino (1912) 6436.

${ }^{99} \mathrm{FA}, \mathrm{TPH}$, Ruokonen, Paavo Alvart 6368.

${ }^{100}$ FA, TPH, Saario, Urho (1912) 6374.

${ }^{101}$ Donson (2010), 170-72; Ziino (2018), 231.

${ }^{102}$ FA, TPH, Salminen, Urpo (1913) 6252.

${ }^{103}$ FA, TPH, Lindholm, Eino (1912) 6436. 


\section{CONCLUSION}

After the war, the children of the Reds experienced the feeling, in a multitude of ways, that they belonged to the losers of the war. They were marginalized in the nation. Their encounters with the nation represented a contradictory process during the 1920s. As Josephine Hoegaerts points out, patriotic love can be compared to a family-based model of affection, and the "love of the fatherland was a generational practice, passed on from one generation to the next and therefore as open to change as it was rooted in history and tradition." 104 The children of the Reds could not learn to love the fatherland which they connected with the White winners' experiences during and after the Civil War. The children were divided into Reds and Whites, and as Eino characterized it, the class war was ongoing among children. The children's war games expressed children's emotions and were one form of resistance. This kind of action encouraged one to express emotions. In the life-story interviews, words like "sorrow," "grief," "tears" and "cry" are usually not used. Only Eino used these words when telling how angry he was at the unveiling ceremony of the Statue of Freedom. He cried silently and said that he then decided to be a workingclass man until his death. ${ }^{105}$

The children and young people lived at emotional frontiers, and they had to try to respond to the different demands and expectations at home, at school and on the playgrounds. This situation was especially difficult for those children who were transferred back and forth from home to foster homes and children's homes. The children were active in their agency through showing initiative during those dangerous and difficult days. In children's games, the war was fought over and over again.

The children followed the life around them and wanted to participate in helping their mothers to support the family. The emotions of excitement, bitterness and humiliation during the war and in its aftermath belonged to the life of children and young people. Hunger and poverty left them with the feeling that no one cared about them when they tried, together with a widowed mother, to stay alive.

The life-story interviews convey intensive emotions connected with war time in 1918. Those emotions have been shaped into experiences and

\footnotetext{
${ }^{104}$ Hoegaerts (2020), 68.

${ }^{105}$ FA, TPH, Lindholm, Eino (1912) 6436.
} 
have had different influences on the life courses of the people involved. Elsa Kolinen was a 15-year-old girl when her father was shot: "We kids observed when those to be shot were transported. [...] I will never forget the emotions that I experienced then." Elsa soon went to work in a cotton mill, enrolled in evening classes and became a member of the Social Democratic Party. All that she saw after the war made her feel solidarity with the working class. During the following decades, she occupied several posts of trust within the municipal organization of Tampere.

Open Access This chapter is licensed under the terms of the Creative Commons Attribution 4.0 International License (http://creativecommons.org/licenses/ by $/ 4.0 /)$, which permits use, sharing, adaptation, distribution and reproduction in any medium or format, as long as you give appropriate credit to the original author(s) and the source, provide a link to the Creative Commons licence and indicate if changes were made.

The images or other third party material in this chapter are included in the chapter's Creative Commons licence, unless indicated otherwise in a credit line to the material. If material is not included in the chapter's Creative Commons licence and your intended use is not permitted by statutory regulation or exceeds the permitted use, you will need to obtain permission directly from the copyright holder.

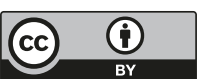

